\title{
NUTRITIONAL EVALUATION OF SUNFLOWER STALKS SILAGE IN RUMINANTS
}

\author{
R. I. Moawd ${ }^{1}$, R.E.A. El-Sharayhi ${ }^{2}$ and M.H. Talha ${ }^{1}$ \\ 1- Animal Production Research Institute, Agricultural Research Center, Egypt, 2- \\ Field Crops Research Institute, Agricultural Research Center, Egypt

\section{SUMMARY}

This work aimed to evaluate effects of feeding the silage of sunflower stalks- local line 102 - (SSS) on nutrients digestibility, DM intake, milk yield and composition and economic impact. Two trials were conducted to achieve this aim. The first one was a digestibility trial on adult rams (65 $\mathrm{kg}$ in average) to determine digestion coefficients and nutritive values of three types of silage made from sunflower stalks with adding $0.5 \%$ urea and $5 \%$ molasses at ensiling:

- Ensiled alone (SSS).

- mixed with corn stalks at ensiling (SS - CS) silage.

- or ensiling corn stalks alone (CSS).

The second one was a feeding trial plus digestibility trial carried out to investigate the effects of incorporating different types of silage in lactating buffaloes' rations (570 $\mathrm{kg}$ in average) on their productive performance using "Swing over" method. The rations were formulated as follows:

- Control ration (CR): $50 \%$ of TDN and CP total requirements from concentrate feed mixture $(C F M)+C S S$ ad - lib.

- First tested ration (TR1): 50\% of TDN and CP total requirements from $C F M+(S S$ - CS) silage ad-lib.

- Second tested ration (TR2): 50\% of TDN and CP total requirements from CFM + SSS ad-lib.

The results of the digestibility trial revealed that, SSS had higher DM, CP, CF, EE and ash contents and lower OM and NFE contents than CSS. Daily DM intake of SSS by sheep was significantly $(p<0.05)$ higher than other tested silages. Dry matter, $O M$ and NFE digestion coefficients and TDN of SSS were significantly $(p<0.05)$ lower than CSS, while CP digestibility, EE digestibility and DCP were significantly $(p<0.05)$ higher.

In the feeding trial, buffaloes consumed similar amount of DM from the three rations. No significant differences were recorded in digestibility coefficients of DM, $C F$ and EE among different experimental rations. The digestibility coefficient of $C P$ of TR1 and TR2 was significantly $(p<0.05)$ higher than CR. A significant $(p<0.05)$ lower TDN value was recorded for TR2 compared to $C R$ and TR1, while DCP was significantly $(p<0.05)$ higher.

Milk yield, fat corrected milk (FCM) and fat yield of animals fed TR2 recorded significant $(p<0.05)$ decreases compared to those fed CR and TR1 without significance between $C R$ and TR1. There were no significant differences among rations regarding milk composition.

Issued by The Egyptian Society of Animal Production 
Incorporation of SSS in lactating buffaloes' rations (TR1 and TR2) reduced feeding cost compared to that of animals fed $C R$.

Sunflower stalks silage, ensiled alone or mixed with corn stalks enriched with urea and molasses at ensiling could be incorporated in lactating buffalo's rations up to $50 \%$ from $T D N$ and $C P$ requirements.

Keywords: Sunflower stalks silage, lactating buffaloes, digestibility, and milk production

\section{INTRODUCTION}

Feed costs the single largest expense in animal production, may be reduced by including locally grown crops and by-products into animals diets especially for ruminants. Since ruminants are essentially recyclers, the use of by products is suited to dairy animals that produce a high quality product (milk) from crops by-products. So, environmentally, as well as economically, by-products will continue to become more important as ingredients in ruminants diets. On the other hand, local production of oilseeds required for human consumption and soap manufactures is too short than covering the nations needs. Sunflower (Helianthus annus L.) is an important oilseed crop in the world. During the last years interest of sunflower as an oil crop was increased in Egypt.

Sunflower could be introduced as a dual purpose crop for both oil and forage production (El-Naklawy, 1993); It could be used for silage making (McGuffey and Schingoether, 1980) or fed as a green fodder (Ladan et al., 1973). Harper et al. (1981) found that sunflower may be a dependable source of roughage in drier climates because of its relatively high drought resistance. Bakshi et al. (1990) found that sunflower chaff silage considered comparable in nutritive value to maize silage. Moreover, Tabana (1994) reported that, sunflower plant residues could be used as a new potential roughage source for ruminants in Egypt. Sabbah et al. (1994) reported that using sunflower stalks silage in ruminants feeding may participate in increasing feed resources, decreasing feeding cost and alleviating the environmental pollution. Rasool et al. (1998) reported that sunflower crop residues such as stalks and heads provide good quality forage for livestock. Sunflower leaves, before being ripe, are used as forage suitable for cattle and sheep. Its protein content is higher (3.6\%) than corn leaves content (1.5\%) (El-Shakankery, 2004). Fisher et al. (1993) reported that, intercropped sunflower-maize harvested and preserved as silage is an acceptable source of forage for lactating cows. Silva et al. (2004) found that, partial replacement of corn silage by sunflower silage did not affect milk, fat and protein yield. Demirel et al. (2006) found that, better quality silage could be obtained by mixing sorghum and sunflower at $50 \%$ ratio.

The objectives of this work were to investigate: 1) nutritional evaluation of sunflower stalks silage (local line-102) compared to corn stalks silage (Sc10) by sheep. 2) Impact of feeding diets containing sunflower stalks silage on performance of lactating buffaloes in terms of milk yield and composition and economic impact.

\section{MATERIALS AND METHODS}

This work was conducted at: EL-Gemmeza Animal Production Research Station, Animal Production Research Institute and El-Gemmeza Agriculture Research Station Farm, Field Crops Research Institute. 
Both are belonging to Agricultural Research Center during years 2005 - 2007 to evaluate sunflower stalks silage (local line-102) compared to corn stalks silage (Sc10) by sheep in terms of nutrients' digestion coefficients and nutritive values as TDN and DCP. Moreover, to study the effects of feeding diets containing sunflower stalks silage on performance of lactating buffaloes in terms of milk yield and composition and economic impact. Two trials were carried out to achieve this aim.

\section{First trial, Silage evaluation}

Cultivation process of this work was carried out at El-Gemmeza Agriculture Research Station Farm in two seasons. In the first season three lines of sunflower (G 101; Vedoc and local line- 102) were cultivated under similar conditions to select a fit line in oil production. Results pointed that local line-102 was a suitable line because surpassed in strong canopy; seeds and oil yield and its components. Above all, this line continues to be fresh and strong after seed physiological mature and it is wide spreading around the country. Moreover, this line has high tolerance to Egyptian environmental conditions indicating a high stability. Depending on first season results, sunflower (local line- 102) has been cultivated in second season.

In the second season, after harvesting sunflower (local line- 102) and corn (Single cross 10 hybrid), whole plant residues were chopped to $2-5 \mathrm{~cm}$.

Sunflower stalks (SS) and corn stalks (CS) were used in preparing: 100\% SS; 50: $50 \% \mathrm{SS}$ : CS and $100 \% \mathrm{CS}$; w/ w on wet basis and were ensiled after mixing with $0.5 \%$ urea and $5 \%$ molasses. The silages from CS, (SS - CS) and SS were conserved in cement silos of 10 tons capacity/ each and were well pressed and covered tightly with plastic sheet and soil to guarantee anaerobic conditions. After ensiling period 2 months - color and odor were examined and silage quality was measured according to method of Research Institute for cattle feeding at Hoorn as described by El Hossieny (1979).

Three digestibility trials was carried out using 9 adult Suffolk crossbred rams (65 $\mathrm{kg}$ in average), 3 rams per each to determine digestion coefficients and nutritive values of the three silages made. The trial period consisted of 21 days as preliminary period followed by 7 days for collection period of feces. Rams were kept and fed individually in metabolic cages. Ninety percent of ad-lib intake of tested silages as a sole feed was offered for each ram (in two meals at 8.00 am and $4.00 \mathrm{pm}$ ) during collection day's period. Water was available all times. Representative samples of feeds and feces were analyzed according to A. O. A. C (1990).

\section{Second trial, feeding trial}

Eight lactating buffaloes, about $570 \mathrm{~kg}$ body weights in the $2^{\text {nd }}-4^{\text {th }}$ parity were selected randomly at their peak of lactation to conduct this work. The "Swing over" method described by (Kellner, 1924; Abou-hussein, 1958 and Abou-Raya, 1978) was applied. Milk production experiment extended for 144 days including four periods. Each period consisted of 21 days as transition period followed by 15 days as experimental period for milk recording, sampling and digestibility trails (Fig. 1). Total requirements of buffaloes was adjusted at beginning each transition period according to changing in milk production and body weight. Animals were individually fed according to NRC (1988) the following experimental rations:

- Control ration (CR): $50 \%$ of $\mathrm{TDN}$ and $\mathrm{CP}$ total requirements from oncentrates feed mixture (CFM) + corn stalks silage (CSS) ad - lib. 
- First tested ration (TR1): $50 \%$ of TDN and $\mathrm{CP}$ total requirements from (CFM) + (SS - CS) silage $a d-l i b$.

- Second tested ration (TR2): $50 \%$ of TDN and CP total requirements from (CFM) + sunflower stalks silage (SSS) $a d-l i b$.
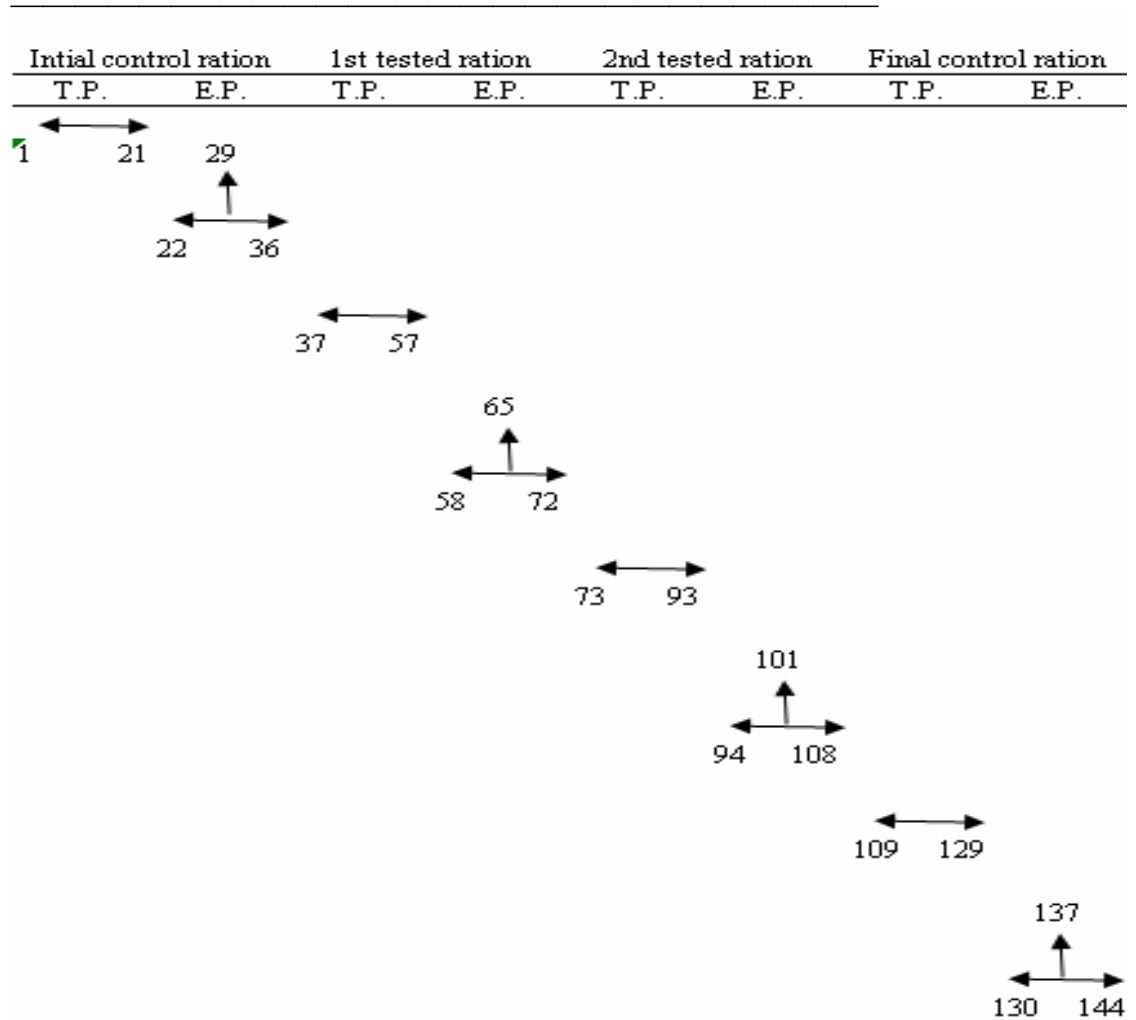

T: Middle days.

T.P. $=$ Transition period.

E.P. $=$ Experimental period.

Fig. 1. Succession of days and periods in the "Swing over" method which included two tested rations, with lactating animals

The CR was fed in the first and last periods, while the two tested rations (TR1 \& TR2) were given in the two medium periods. The nutritive values of CFM on DM basis (calculated by indirect method according to Abou - Raya, 1967) were 63.65 and 12.20 for TDN and DCP respectively.

Three digestibility trails were carried out on feeding trail animals (three buffaloes per each) during experimental period of each period to determine digestion coefficients and nutritive values of rations contain different tested silages. Fecal grab 
samples of about $500 \mathrm{~g}$ were taken from the rectum three times daily for five days as collection period. Acid insoluble ash (AIA) was used as natural marker for nutrients digestibility determination (Van Keuleun and Young, 1977). Representative samples of feeds and feces were analyzed according to A. O. A. C. (1990).

Milk yield and milk fat percent were recorded daily and individually for all animals during experimental period of each period. The 7\% FCM produced for each buffalo was calculated from daily milk yield and milk fat percent using following formula given by Raafat and Saleh (1962), 7\% FCM $=0.265$ milk yield +10.50 fat yield. Milk samples were taken in the middle days of each experimental period (29, 65, 101 and 137 days) from each buffalo individually. Milk samples were analyzed for protein, total solids (TS) and ash according to A. O. A. C. (1990), while lactose was estimated by difference. Milk fat was determined according to Gerber's method as described by Ling (1963).

Feed conversion was calculated for the experimental rations as the amount of DM, TDN and DCP in $\mathrm{kg}$ required to produce one $\mathrm{kg} 7 \%$ FCM. Economic efficiency of milk production was expressed as the ratio between FCM produced price and daily feeding cost.

Data was statistically analyzed using SPSS Inc (1999). Differences among means were tested for significance by Duncan's multiple range test (Duncan, 1955).

\section{RESULTS AND DISCUSSION \\ First trial, Silage evaluation \\ Chemical composition}

Data in table (1) show superiority of sunflower stalks silage (SSS) in DM, CP, CF and EE contents and lower OM and NFE contents than corn stalks silage (CSS), while, sunflower - corn stalks silage (SS - CS) silage had an intermediate values of chemical composition.

Table 1. Chemical composition of ingredients and experimental rations

\begin{tabular}{|c|c|c|c|c|c|c|c|}
\hline \multirow[t]{3}{*}{ Items } & \multirow{3}{*}{ DM\% } & \multicolumn{6}{|c|}{ Composition of feeds used in both trials on } \\
\hline & & \multicolumn{6}{|c|}{ DM basis, $\%$} \\
\hline & & OM & $\mathbf{C P}$ & $\mathbf{C F}$ & $\mathbf{E E}$ & NFE & Ash \\
\hline $\begin{array}{l}\text { Concentrate feed mixture } \\
(\mathrm{CFM})^{*}\end{array}$ & 90.65 & 88.45 & 16.80 & 12.74 & 3.30 & 55.61 & 11.55 \\
\hline $\begin{array}{l}\text { Sunflower stalks silage } \\
\text { (SSS) }\end{array}$ & 33.40 & 87.68 & 11.96 & 30.14 & 3.28 & 42.30 & 12.32 \\
\hline Corn stalks silage (CSS) & 31.65 & 89.81 & 9.22 & 29.86 & 1.96 & 48.77 & 10.19 \\
\hline $\begin{array}{l}\text { Sunflower - corn stalks } \\
\text { (SS - CS) silage. }\end{array}$ & 32.27 & 88.54 & 10.70 & 29.98 & 2.58 & 45.28 & 11.46 \\
\hline \multicolumn{8}{|c|}{ Calculated composition of tested rations used in feeding trial: } \\
\hline $\begin{array}{l}\text { CR 50\% CFM + CSS ad. } \\
\text { lib. }\end{array}$ & 43.23 & 89.25 & 12.34 & 22.81 & 2.51 & 51.59 & 10.75 \\
\hline $\begin{array}{l}\text { TR1 } 50 \% \text { CFM + (SS - } \\
\text { CS) silage } a d . l i b .\end{array}$ & 43.65 & 88.50 & 13.17 & 23.00 & 2.88 & 49.45 & 11.50 \\
\hline $\begin{array}{l}\text { TR2 } 50 \% \text { CFM + SSS } \\
\text { ad. lib. }\end{array}$ & 44.11 & 87.97 & 13.82 & 23.46 & 3.29 & 47.40 & 12.03 \\
\hline
\end{tabular}


These data were within the range reported by Boza et al. (1983) and Sabbah et al. (1994) for SSS and Etman et al. (1994) and Mostafa et al. (2000) for CSS. Since all experimental crops were planted under similar conditions, so the differences in the chemical composition could be related to different species of these crops and should produce silages characterized with different quality and nutritive values (Khalafalla et al., 2007). The differences in chemical composition of experimental rations were mainly a reflection of the chemical composition and the proportion of the experimental feedstuffs (Table 1).

\section{Silage quality}

Results of silage quality (Table 2) indicated that, the three silages had a good physical characteristics (natural color and pleasant aroma) as well as a good fermentation quality expressed as low $\mathrm{pH}$ (3.90 to 4.02), high lactic acid content (3.50 to 3.80) while little contents of ammonia ( 0.09 to 0.15$)$ and butyric acid $(0.08$ to 0.12). Similar trend was observed by Etman et al. (1994), Tabana (1994) and Mostafa et al. (2000) with the same silage types.

Table 2. Quality characteristics of different types of silage

\begin{tabular}{lccc}
\hline Items & $\begin{array}{l}\text { Sunflower } \\
\text { stalks silage }\end{array}$ & $\begin{array}{l}\text { Sunflower } \\
- \text { corn } \\
\text { stalks } \\
\text { silage }\end{array}$ & $\begin{array}{l}\text { Corn } \\
\text { stalks } \\
\text { silage }\end{array}$ \\
\hline $\mathrm{pH}$ & 4.02 & 3.97 & 3.90 \\
Total acidity (ml NaOH/ 100gm silage) & 26.10 & 26.85 & 27.20 \\
Ammonia - N (per 100 gm silage) & 0.15 & 0.11 & 0.09 \\
Acetic acid (per 100 gm silage) & 0.63 & 0.74 & 0.81 \\
Butyric acid (per 100 gm silage) & 0.12 & 0.09 & 0.08 \\
Lactic acid (per 100 gm silage) & 3.50 & 3.72 & 3.80 \\
\hline
\end{tabular}

\section{Feed intake}

Dry matter intake (DMI) expressed either as $\mathrm{kg} / 100 \mathrm{LBW}$ or $\mathrm{gm} / \mathrm{kg} \mathrm{w}^{0.75}$ were significantly $(p<0.05)$ higher for SSS than those for other silages (Table 3). No significant differences were found in DMI between CSS and (SS - CS) silage. Higher DMI of SSS may be due to good palatability and high DM content (Krivoruchenko, 1995). These results agree with those reported by Thomes et al. (1982) and Tabana (1994) who found that DMI was 2.57 and $1.99 \mathrm{~kg} / 100 \mathrm{~kg} \mathrm{LBW}$ for SSS and CSS, respectively with sheep.

\section{Digestibility}

Data in table (3) revealed that digestion coefficients of DM, OM and NFE of SSS were significantly $(\mathrm{p}<0.05)$ lower than those of other silages, while the differences between CSS and (SS - CS) silage were not significant. The reduction in DM digestibility of SSS may be due to higher silage DMI (Tyrrell and Moe, 1975). On the other hand, CP digestibility of SSS and (SS - CS) silage was significantly $(p<0.05)$ higher than that of CSS. This may be attributed to lower CP content of CSS as shown in table (1). Similar results were obtained by Tabana (1994) who found that CP digestibility was 66.76 and $58.95 \%$ for SSS and CSS, respectively by sheep. CF digestibility showed that there were no significant differences between tested silages. 
EE digestibility of SSS was significantly $(p<0.05)$ higher than that of CSS, but insignificantly higher than that of (SS - CS) silage. This may be attributed to higher EE content of SSS than CSS (Table 1). Similar results were obtained by Valdez et al. (1988a).

The differences in digestion coefficients between present results and those reported by other workers may be due to variation in chemical composition and ensiling processing. This variation can affect silage quality and consequently nutrients digestibility and feeding value of silages (Tabana, 1994).

Table 3. Feed intake, digestibility and nutritive values of sunflower stalks, sunflower - corn stalks and corn stalks silages by sheep

\begin{tabular}{llll}
\hline Items & $\begin{array}{l}\text { Sunflower } \\
\text { stalks silage }\end{array}$ & $\begin{array}{l}\text { Sunflower }- \\
\text { corn stalks } \\
\text { silage }\end{array}$ & $\begin{array}{l}\text { Corn stalks } \\
\text { silage }\end{array}$ \\
\hline DM intake: & & & \\
Kg/ $100 \mathrm{~kg} \mathrm{LBW}$ & $2.38^{\mathrm{a}} \pm 0.04$ & $2.26^{\mathrm{b}} \pm 0.02$ & $2.21^{\mathrm{b}} \pm 0.01$ \\
g/ kg W & $67.72^{\mathrm{a}} \pm 1.11$ & $64.30^{\mathrm{b}} \pm 0.50$ & $62.72^{\mathrm{b}} \pm 0.47$ \\
Digestion coefficients\%: & & & \\
DM & $60.18^{\mathrm{b}} \pm 0.19$ & $61.82^{\mathrm{a}} \pm 0.42$ & $62.45^{\mathrm{a}} \pm 0.31$ \\
OM & $62.33^{\mathrm{b}} \pm 0.31$ & $64.71^{\mathrm{a}} \pm 0.26$ & $64.93^{\mathrm{a}} \pm 0.29$ \\
$\mathrm{CP}$ & $64.65^{\mathrm{a}} \pm 0.60$ & $63.72^{\mathrm{a}} \pm 0.37$ & $59.68^{\mathrm{b}} \pm 0.50$ \\
$\mathrm{CF}$ & $60.73^{\mathrm{a}} \pm 0.44$ & $61.68 \pm 0.63$ & $62.90 \pm 0.65$ \\
EE & $76.20^{\mathrm{a}} \pm 0.33$ & $74.90^{\mathrm{ab}} \pm 0.55$ & $72.93^{\mathrm{b}} \pm 0.85$ \\
NFE & $61.75^{\mathrm{b}} \pm 0.84$ & $66.36^{\mathrm{a}} \pm 0.77$ & $66.85^{\mathrm{a}} \pm 0.91$ \\
Nutritive values\%: & & & \\
TDN & $57.78^{\mathrm{b}} \pm 0.28$ & $59.70^{\mathrm{a}} \pm 0.25$ & $60.10^{\mathrm{a}} \pm 0.23$ \\
DCP & $7.73^{\mathrm{a}} \pm 0.07$ & $6.82^{\mathrm{b}} \pm 0.04$ & $5.50^{\mathrm{c}} \pm 0.05$ \\
\hline a, b and c: Means within the same row with different superscripts differ $(\mathrm{p}<0.05)$. &
\end{tabular}

On the other hand the improvement in digestion coefficients of most nutrients of (SS - CS) silage could be due to associated effect of mixing sunflower and corn stalks at ensiling on fermentation process during ensiling period (Soliman et al., 1997; and El-Tahan et al., 2003) with other silage mixtures that consequently reflected on better conditions of rumen fermentation (Shehata et al.,2003).

\section{Nutritive values}

Data in table (3) showed that, SSS had significant $(\mathrm{p}<0.05)$ lowest TDN value $(57.78 \%)$ and highest DCP value $(7.73 \%)$ compared to the other silages. The lowest TDN content of SSS may be due to lower digestion coefficients of DM, OM and NFE compared to other silages. Whereas, the higher DCP content could be attributed to higher CP content and its digestion for SSS compared to other silages. Tabana (1994) recoded a lower TDN value and higher DCP value of SSS than those obtained herein. This may be due to the different varieties, agriculture practices, environmental conditions and stage of maturity involved at ensiling (Khalafalla et al., 2007).

The improvement $(\mathrm{p}<0.05)$ in TDN and DCP values of (SS - CS) silage compared to SSS and CSS, respectively could be referred to the associated effect of types of silages (Shehata et al., 2003). 
From previous data, it could be concluded that, sunflower stalks silage ensiled alone or mixed with corn stalks enriched with urea and molasses at ensiling time is a suitable quality roughage for ruminants which had a good palatability and had adequate feeding values.

\section{Second trial, feeding trial \\ Feed intake}

Total DMI of three rations fed to lactating buffaloes expressed as either $\mathrm{kg} / \mathrm{head} /$ day or $\mathrm{kg} / \mathrm{kg} \mathrm{w}^{0.75}$ were nearly similar (Table 4). These results are in agreement with Vandersall (1976) and Valdez et al. (1988b).

Table 4. Feed intake, digestibility and nutritive values of experimental rations by lactating buffaloes

\begin{tabular}{lccc}
\hline Items & CR & TR1 & TR2 \\
\hline Live body weight kg & $575.00 \pm 9.94$ & $580.33 \pm 9.24$ & $584.67 \pm 8.69$ \\
Daily DMI kg/ h/ d: & & & \\
CFM & 6.49 & 6.47 & 6.21 \\
CSS & 9.28 & - & - \\
(SS - CS) silage & - & 9.51 & - \\
SSS & - & - & 9.95 \\
Total DMI, kg/ h/ d & $15.77 \pm 0.33$ & $15.98 \pm 0.27$ & $16.16 \pm 0.38$ \\
Total DMI, kg/ kg W ${ }^{0.75}$ & $0.134 \pm 0.004$ & $0.135 \pm 0.007$ & $0.136 \pm 0.003$ \\
Digestion coefficients\%: & & & \\
DM & $65.57 \pm 0.73$ & $64.75 \pm 0.69$ & $62.41 \pm 0.81$ \\
OM & $68.40^{\mathrm{a}} \pm 0.46$ & $67.87^{\mathrm{a}} \pm 0.33$ & $63.61^{\mathrm{b}} \pm 0.31$ \\
CP & $62.70^{\mathrm{b}} \pm 0.74$ & $66.16^{\mathrm{a}} \pm 0.92$ & $66.81^{\mathrm{a}} \pm 0.87$ \\
CF & $57.96 \pm 0.87$ & $57.56 \pm 0.53$ & $56.16 \pm 0.66$ \\
EE & $76.55 \pm 0.54$ & $78.42^{\mathrm{a}} \pm 0.74$ & $79.13 \pm 0.48$ \\
NFE & $73.98^{\mathrm{a}} \pm 0.71$ & $72.52^{\mathrm{a}} \pm 0.82$ & $65.28^{\mathrm{b}} \pm 0.58$ \\
Nutritive values\%: & & & \\
TDN & $63.45^{\mathrm{a}} \pm 0.42$ & $62.90^{\mathrm{a}} \pm 0.31$ & $59.20^{\mathrm{b}} \pm 0.28$ \\
DCP & $7.74^{\mathrm{c}} \pm 0.12$ & $8.71^{\mathrm{b}} \pm 0.14$ & $9.23^{\mathrm{a}} \pm 0.11$ \\
\hline a, b and c: Means within the same row with different superscripts differ $(\mathrm{p}<0.05)$. &
\end{tabular}

\section{Digestibility}

Decrease of CF digestibility for experimental rations (Table 4) compared to corresponding values for different silage types (Table 3) may be due to higher NFE content of rations. While digestion cofficints of other nutrients and feeding values were increased. These results would be expected as a results to CFM integration into different rations. Nevertheless, differences were not significant between three rations regarding DM, CF and EE digestibilities. Otherwise, OM and NFE digestibilities of TR2 were significantly $(\mathrm{p}<0.05)$ lower than those of other rations. On the other hand, CP digestibilities of TR1 and TR2 were significantly $(p<0.05)$ higher than CR. This may be attributed to higher CP content of TR1 and TR2 as shown in table (1).

From previous data, it could be noticed that, TR2 had lower digestibility of most nutrients than other rations might be due to lower the digestibility of most nutrients of SSS (Table 3), while ration TR1 had an intermediate values. 


\section{Nutritive values}

TDN\% of TR2 was significant $(\mathrm{p}<0.05)$ lower compared to that of CR and TR1 (Table 4). This may be due to lower digestibilities of most nutrients for ration TR2 compared to other rations. Otherwise, DCP\% of TR2 showed significant $(\mathrm{p}<0.05)$ increase compared to that of CR and TR1, this may be due to higher CP content and its digestion of TR2 compared to other rations.

Replacing $100 \%$ CSS by SSS as a sole roughage portion (TR2) decreased $(\mathrm{p}<0.05)$ TDN\% compared to TR1 which contain (SS - CS) silage. These differences might be due to the higher most nutrient digestbilities of CSS than SSS as shown in table (3). These results are in harmony with those reported by Tabana (1994) who found that CSS had higher TDN value compared to SSS.

From previous data, it could be noticed that, TR1 showed medium feeding value between CR and TR2, this may be due to associative effect of digestibility which reflected on nutritive values (Osman et al., 2007).

\section{Milk yield and composition}

Average daily actual milk yield (Table 5) of lactating buffaloes fed initial control ration (CR) was $10.15 \mathrm{~kg} / \mathrm{head} /$ day, while average daily milk yield as calculated for buffaloes fed $1^{\text {st }}$ and $2^{\text {nd }}$ tested rations (TR1 and TR2) were 9.89 and $9.22 \mathrm{~kg} / \mathrm{head} /$ day, respectively. Milk yield was decreased by 2.56 and $9.16 \%$ for TR1 and TR2, respectively. The data observed that buffaloes fed TR2 had lower $(p<0.05)$ milk production than buffaloes fed CR and TR1. No significant differences of milk yield between CR and TR1. The same trend was obtained with 7\% FCM yield and fat yield of buffaloes fed the same experimental rations. These results may be attributed to the higher digestibilities of most nutrients and TDN value for CR and TR1 than TR2 (Table 4). These results were agreement with Valdez et al. (1988b) who found that, FCM yield of cows fed rations containing corn silage or corn - sunflower silage was higher $(\mathrm{p}<0.05)$ than that of produced by cows fed sunflower ensiled alone. Silva et al. (2004) found that, partial replacement of corn silage with sunflower silage in lactating cows' diets did not affect milk, fat and protein yield.

Table 5. Effect of feeding different experimental rations on productive responses of lactating buffaloes

\begin{tabular}{|c|c|c|c|}
\hline Items & $\begin{array}{c}\text { Milk yield } \\
\text { kg/ head/ day }\end{array}$ & $\begin{array}{c}\% \text { FCM } \\
\text { yield } \mathrm{kg} / \\
\text { head/ day }\end{array}$ & $\begin{array}{c}\text { Fat yield } \\
\text { g/head/ day }\end{array}$ \\
\hline $\begin{array}{l}\text { Initial yield of control ration } \\
1^{\text {st }} \text { tested ration: }\end{array}$ & $10.15^{j} \pm 0.22$ & $9.33^{j} \pm 0.18$ & $632^{j} \pm 11.75$ \\
\hline Actual yield & 9.28 & 8.81 & 605 \\
\hline Calculated yield $A+F(65-29)(G)$ & $9.89^{\mathrm{j}} \pm 0.24$ & $9.21^{\mathrm{j}} \pm 0.20$ & $629^{j} \pm 13.40$ \\
\hline $\begin{array}{l}\text { Difference } \mathrm{G}-\mathrm{A} / \mathrm{A} \times 100 \\
2^{\text {nd }} \text { tested ration: }\end{array}$ & -2.56 & -1.29 & -0.47 \\
\hline Actual yield & 8.00 & 7.66 & 528 \\
\hline Calculated yield $\mathrm{C}+\mathrm{F}(101-29)(\mathrm{H})$ & $9.22^{\mathrm{k}} \pm 0.19$ & $8.45^{\mathrm{k}} \pm 0.19$ & $576^{\mathrm{k}} \pm 13.35$ \\
\hline Difference $\mathrm{H}-\mathrm{A} / \mathrm{A}$ x 100 & -9.16 & -9.43 & -8.86 \\
\hline Final yield of control ration & 8.33 & 8.10 & 561 \\
\hline Daily decrease A - D / 137-29 (g)(F) & 17 & 11 & 0.66 \\
\hline
\end{tabular}


Regarding average milk yield, the current results are nearly similar with those reported by El - Ashry et al. (2001) and Saleh et al. (2003) for lactating buffaloes fed rations contained $50 \%$ concentrate and $50 \%$ roughage.

Milk composition as TS, SNF, fat, protein, lactose and ash\% of lactating buffaloes fed experimental rations showed no significant differences (Table 6). While TS, fat, SNF and protein $\%$ increased with TR2 than other rations. Improving milk fat content in TR2 was associated with increased EE intake (McGuffey and Schingoether, 1980 and Thomas eat al., 1982). Also, improving milk fat content in TR2 was associated with a decrease in milk yield in this group compared to those fed $\mathrm{CR}$ and TR1. These results can be explained by the fact, that fat $\%$ decrease as milk yield increase. Jinlong and Yanglian (2001) found that, milk fat\% was negatively correlated with milk yield. The results of milk composition were within the normal values which agree with Saleh et al. (2003) for buffaloes' milk.

Table 6. Milk composition \% of lactating buffaloes fed experimental rations

\begin{tabular}{lccccc}
\hline Items & \multicolumn{5}{c}{ Experimental rations } \\
\cline { 2 - 6 } & Initial CR & TR1 & TR2 & Final CR & $\begin{array}{c}\text { Average } \\
\text { two CR }\end{array}$ \\
\hline TS & $16.02 \pm 0.08$ & $16.31 \pm 0.09$ & $16.47 \pm 0.08$ & $16.46 \pm 0.11$ & $16.24 \pm 0.07$ \\
Fat & $6.30 \pm 0.04$ & $6.53 \pm 0.06$ & $6.65 \pm 0.07$ & $6.66 \pm 0.08$ & $6.48 \pm 0.05$ \\
SNF & $9.72 \pm 0.07$ & $9.78 \pm 0.04$ & $9.82 \pm 0.03$ & $9.80 \pm 0.08$ & $9.76 \pm 0.03$ \\
Protein & $4.23 \pm 0.05$ & $4.24 \pm 0.03$ & $4.28 \pm 0.04$ & $4.15 \pm 0.07$ & $4.19 \pm 0.02$ \\
Lactose & $4.62 \pm 0.06$ & $4.63 \pm 0.04$ & $4.61 \pm 0.05$ & $4.72 \pm 0.08$ & $4.67 \pm 0.05$ \\
Ash & $0.87 \pm 0.03$ & $0.91 \pm 0.07$ & $0.93 \pm 0.03$ & $0.93 \pm 0.06$ & $0.90 \pm 0.04$ \\
\hline
\end{tabular}

No significant differences among all treatments.

$\mathrm{TS}=$ Total solids $\quad \mathrm{SNF}=$ Sold non fat.

Feed intake and conversion and economic efficiency

From data in table (7), it was observed that, the total DMI of three rations expressed as $\mathrm{kg} / \mathrm{head} / \mathrm{day}$ or $\mathrm{kg} / \mathrm{kg} \mathrm{w}^{0.075}$ were nearly similar. These results were agreement with Vandersall, (1976) and Valdez et al. (1988b). TDN intake as kg/ head/ day or $\mathrm{g} / \mathrm{kg} \mathrm{w}^{0.075}$ of TR2 was significant $(\mathrm{p}<0.05)$ lower than those of CR and TR1. This may be due to lower $(\mathrm{p}<0.05)$ TDN\% for ration TR2 than other rations (Table 4). Otherwise, DCP intake of TR2 either as $\mathrm{kg} /$ head/ day or $\mathrm{g} / \mathrm{kg} \mathrm{W} \mathrm{W}^{0.075}$ were higher $(p<0.05)$ than those of the others. This increase may be due to the higher nutritive value as DCP for ration TR2 than other rations (Table 4).

Buffaloes fed ration TR2 showed the lowest values $(\mathrm{p}<0.05)$ of DM and DCP conversion (Table 7) than those fed CR and TR1. While, buffaloes fed TR2 showed the lowest value $(\mathrm{p}<0.05)$ of TDN conversion than those fed CR only. On the other hand, DM and TDN conversion were similar for buffaloes fed CR and TR1. These results can be attributed to the differences in milk production, feed intake and nutritive values of the tested rations. Mir et al. (1992) found that, the differences in efficiency of utilization of the silages may be due to differences in digestion in the rumen and intestines.

Feeding cost per kg FCM produced were 197.24; 186.38 and 185.73 P.T. for CR, TR1 and TR2, respectively (Table 7). It was noticed that feeding cost/ kg FCM produced decreased by $5.51 \%$ and $5.84 \%$ for milk produced by buffaloes fed rations containing SSS (TR1 and TR2) compared to CR. Better economic efficiency 
obtained with TR1 and TR2 may be to decreasing feed cost of these rations compared to CR. These results are in agreement with Rasool et al. (1998) and Rao et al. (1999).

Table 7. Average daily feed intake, feed conversion and economic efficiency for lactating buffaloes fed different experimental rations

\begin{tabular}{|c|c|c|c|}
\hline \multirow[b]{2}{*}{ Items } & \multicolumn{3}{|c|}{ Experimental rations } \\
\hline & $\mathbf{C R}$ & TR1 & TR2 \\
\hline \multicolumn{4}{|l|}{ Daily DMI kg/ head/ day: } \\
\hline CFM & 6.52 & 6.49 & 6.32 \\
\hline CSS & 9.21 & - & - \\
\hline (SS - CS) silage & - & 9.35 & - \\
\hline SSS & - & - & 9.73 \\
\hline Total DMI kg/ head/ day & $15.73 \pm 0.26$ & $15.84 \pm 0.19$ & $16.05 \pm 0.24$ \\
\hline Total DMI kg/ $\mathrm{kg} \mathrm{W}^{0.75}$ & $0.134 \pm 0.002$ & $0.134 \pm 0.001$ & $0.135 \pm 0.001$ \\
\hline \multicolumn{4}{|l|}{ Daily feed units intake: } \\
\hline $\begin{array}{l}\text { TDN intake } \mathrm{kg} / \mathrm{h} / \\
\text { day }\end{array}$ & $9.98^{a} \pm 0.16$ & $9.96^{\mathrm{a}} \pm 0.12$ & $9.50^{\mathrm{b}} \pm 0.14$ \\
\hline $\begin{array}{l}\text { TDN intake } \mathrm{g} / \mathrm{kg} \\
\mathrm{W}^{0.75}\end{array}$ & $84.94^{\mathrm{a}} \pm 1.04$ & $84.22^{\mathrm{a}} \pm 0.65$ & $79.86^{\mathrm{b}} \pm 0.66$ \\
\hline $\begin{array}{l}\text { DCP intake } \mathrm{kg} / \mathrm{h} / \\
\text { day }\end{array}$ & $1.22^{\mathrm{c}} \pm 0.02$ & $1.38^{b} \pm 0.02$ & $1.48^{\mathrm{a}} \pm 0.02$ \\
\hline $\begin{array}{l}\text { DCP intake } \mathrm{g} / \mathrm{kg} \\
\mathrm{W}^{0.75}\end{array}$ & $10.38^{c} \pm 0.13$ & $11.67^{b} \pm 0.09$ & $12.44^{\mathrm{a}} \pm 0.10$ \\
\hline Daily $7 \%$ FCM yield $(\mathrm{kg})$ & $9.33^{\mathrm{a}} \pm 0.18$ & $9.21^{\mathrm{a}} \pm 0.20$ & $8.45^{b} \pm 0.19$ \\
\hline \multicolumn{4}{|l|}{ Feed conversion: } \\
\hline $\mathrm{kg} \mathrm{DM} / \mathrm{kg}$ FCM & $1.69^{\mathrm{a}} \pm 0.03$ & $1.72^{\mathrm{a}} \pm 0.02$ & $1.90^{\mathrm{b}} \pm 0.03$ \\
\hline $\mathrm{kg}$ TDN/ kg FCM & $1.07^{\mathrm{a}} \pm 0.02$ & $1.08^{\mathrm{ab}} \pm 0.01$ & $1.12^{\mathrm{b}} \pm 0.02$ \\
\hline $\mathrm{kg} \mathrm{DCP} / \mathrm{kg} \mathrm{FCM}$ & $0.131^{\mathrm{a}} \pm 0.002$ & $0.150^{b} \pm 0.002$ & $0.175^{\mathrm{c}} \pm 0.003$ \\
\hline Feeding cost/ FCM (P.T.) & 197.24 & 186.38 & 185.73 \\
\hline Economic efficiency ${ }^{*}$ & 1.77 & 1.88 & 1.88 \\
\hline \multicolumn{4}{|c|}{$\begin{array}{l}\text { a, b and c: Means within the same row with different superscripts differ }(\mathrm{p}<0.05) \text {. } \\
* \text { Economic efficiency = price of FCM/ price of feeds consumed. }\end{array}$} \\
\hline $\mathrm{CFM}=1750$ & (SS - CS) silage & $\mathrm{SSS}=120$ & Raw milk $=3500$ \\
\hline
\end{tabular}

\section{CONCLUSION}

From previous data, it could be concluded that, sunflower stalks enriched with urea and molasses, ensiled alone or mixed with corn stalks at ensiling, is suitable quality roughage for ruminants. It has a good palatability and adequate feeding value. It could be incorporated in lactating buffaloes rations up to $50 \%$ from TDN and CP requirements. This incorporation led to decrease feeding cost and improved economic efficiency.

\section{REFERENCES}

Abou-Hussein, E.R.M., 1958. Economical feeding of dairy cows and buffaloes for milk production in Egypt. Ph.D . Thesis, Fac. Agric., Cairo Univ., Egypt. 
Abou - Raya, A. K., 1967. Animal and Poultry Nutrition, $1^{\text {st }}$ Edit. Pub. Dar El Maarif, Cairo (Arabic Text Book).

Abou - Raya, A. K., E. R. Abou - Hussein, S. El - Samman, M. M. El Shinnawy and H. M. Sharaf, 1978. The effect of crude fiber level and type of roughage on the yield and quality of milk and fat with Friesian cows. Egypt. J. Anim. Prod., 18: 91 - 103.

A. O. A. C., 1990. Association of Official Analytical Chemists. Official Methods of Analysis $13^{\text {th }}$ ED. Washington D. C., USA.

Bakshi, M. P. S., A. S. Multan and G. S. Makkar, 1990. Utilize sunflower byproducts as livestock feed. India Farming, 35 (12): 15 - 16.

Boza, J., F. J. Munoz, J. E. Guerrero and J. F. Aguilera, 1983. The use of sunflower (Helianthus annuus) stover in goat feeding. 1 - Study of its nutritive value. Estacion Experimental del Zaidin del CSIC, Granada, Spain.

Demirel, M., D. Bolat, S. Celik, Y. Bakici and A. Tekeli, 2006. Evaluation of fermentation qualities and digestibilities of silage mad from sorghum and sunflower alone and the mixtures of sorghum - sunflower. J. Biolo. Sci., 6 (5): $926-930$.

Duncan, D. B., 1955. Multiple Range and Multiple F. test. Biometrics, 11: $1-42$.

El - Ashry, M. A., A. M. Kholif, H. A. El - Alamy, H. M. El - Sayed and T. A. El - Hamamsy, 2001. Effect of different yeast cultures supplementation to diet on the productive performance of lactating buffaloes. Egypt. J. Nutr. and Feeds, 4 (1): 21 - 33.

El - Hosseiny, H. M., 1979. Silage making from berseem. M. Sc. Thesis, Fac. Agric., Zagazig Univ., Egypt.

El - Nakhlawy, F. S., 1993. Defoliation effects on yield, yield components and quality of sunflower. Alex. J. Agric. Res., 38 (3): 257 - 267.

El-Shakankery, Ghad, 2004. Evaluation of sunflower plant as feedstuff for sheep. M.Sc. Thesis, Fac. Agric., Minufiya Univ., Egypt.

El - Tahan, A. A. H., K. M. El - Gendy, G. A. Abd El - Rahman and K. E. I. Etman, 2003. The effect of replacing maize silage with peanut tops silage on performance of lambs. Egypt. J. Nutr. and Feeds, 6 (Special Issue): 1367 1379.

Etman, K. E. I., E. A. Khafagi, W. H. Abdel - Malik, M. K. Hathout and M. F. El - Sayes, 1994. Conservation of green summer forages as silage and its utilization in feeding growing lambs. Egypt. J. Anim. Prod., Vol. 31, Suppl. Issue: $175-189$.

Fisher, L. J., S. Bittman, Z. Mir, P. Mir and J. A. Shelford, 1993. Nutritional evaluation of ensilage made from intercropped corn and sunflowers. Can. J. Anim. Sci., 73 (3): 539 - 545.

Harper, F., E. Donaldson, A. R. Henderson and R. A. Edwards, 1981. The potential of sunflowers as a crop for ensilage and zero - grazing in northern Britain. J. Agric. Sci., Camb. 96: 45.

Jinlong, W. and F. Yanglian, 2001. Prediction of dry matter intake of diets in lactating cows fed with green maize stover silage. Chinese J. Anim. Sci., 37 (4): $13-15$.

Kellner, O., 1924. "Die Ernatring der Iandw. Nulatese" 10 auf 5, 231 (cited from Abou - Raya et al., 1978). 
Khalafalla, M. M., M. K.Mohsen, M. M. Bendary and M. M. El - Nahrawy, 2007. Evaluation of silage made from corn - legumes mixture. Egypt. J. Nutr. and Feeds, 10 (2) Special Issue: $649-661$.

Krivoruchenko, E. P., 1995. Utilization of oilseed radish. All - Russian Soyabean Research Institute, Sadovyi, Amur Region, Russia.

Ladan, P. E., N. N. Belkina and M. I. Gustin, 1973. Change of the nutrient value of fodder plants by vegetative phases. Dokl. Vses. Ordena Lenina Akadskh.Navk Im VI .Lenina. 7: 4.

Ling, E. R., 1963. A Text Book of dairy chemistry. $3^{\text {rd }}$ Ed., Chapman and Hall Ltd., London.

McGuffey, R. K. and D. J. Schingoether, 1980. Feeding value of a high oil variety of sunflowers as silage to lactating dairy cows. J. Dairy Sci., 63: 1109 - 1113.

Mir, Z., P. S. Mir, S. Bittman and J. Fisher, 1992. Ruminal degradation characteristics of corn and corn - sunflower intercropped silages prepared at two stages of maturity. Can. J. Anim. Sci., 72: $881-889$.

Mostafa, M. R. M., M. F. El - Sayes, K.E. I. Etman and M. K. Hathout, 2000. Evaluation of maize stover silage in comparison with whole maize silage in sheep rations. Proc. Conf. Anim. Prod. In The $21^{\text {st }}$ Century, Sakha, 18-20 April 2000: 229 - 236.

NRC, 1988. Nutrient Requirements of Dairy Cattle. $6^{\text {th }}$ Rev. Ed., National Academy Press Washington, DC.

Osman, A. A., E. S. Soliman, F. Z. Swidan and A. N. Ismail, 2007. Effect of feeding silages contained citrus pulp and some crop residues on digestibility and rumen parameters of sheep. Egypt. J. Nutr. and Feeds, 10 (2) Special Issue: $245-262$.

Raafat, N. A. and M. S. Saleh, 1962. Two formulas for the conversion of cow's and buffalo's milk of different fat percentages into milk of standared fat percentage. Proc. of the $1^{\text {st }}$ Anim. Prod. Conf. at Minia: 203.

Rasool, E., M. F. Khan, M. Nawazy and M. Rafiqu, 1998. Utilization of sunflower crop residues as feed in small ruminants. Asian - Australasian J. Anim. Sci., 11 (3): $272-276$.

Rao, K. S., M. R. Reddy, G. V. N. Reddy, 1999. Utilization of sunflower crop residues in the rations of dairy cattle. Department of Feed and Fodder Technology, Acharya N. G. Ranga Agricultureal Unv., College of Veterinary Sci., Hyderabed 500030, India.

Sabbah, M. Allam, M. A. Hanafy, A. Abd El - Baset and A. S. Tabana, 1994. Sunflower plant residues as a feedstuff in ruminants diets.Egypt. J. Anim. Prod., Vol. 31, Suppl. Issue: 135 - 145.

Saleh, M. S., A. M. Metwally, M. I. Bassiouni and M. A. El - Shora, 2003. Utilization of watermelon vine hay in feeding ruminants. II - Effect of replacing berseem hay by watermelon vine hay in feeding lactating buffaloes. Egypt. J. Nutr. and Feeds, 6 (Special Issue): 617 - 626.

Shehata, E. I., M. E. Ahmed, Faten F. Abou Ammou, A. A. M. Soliman and M. El - H. Haggag, 2003. Effect of partial replacement of maize (Zea Maysl.) with reed (Arundo Domax, L) in silage fed to growing Rahmani lambs. Egypt. J. Nutr. and Feeds, 6 (Special Issue): 969 - 980.

Silva, B. O., L. A. Leite, M. I. C. Ferreira, L. M. Fonseca and R. B. Reis, 2004. Sunflower silage and corn silage in lactating cow diets: milk production and 
composition. Arquivo Brasileiro de Medician Veterinria E Zootecnia 56 (6) $750-756$.

Soliman, E. S., A. E. M. Khinizy, Mohamed, K. Bahira and M. El - Haggag, 1997. Studies on using Sasbania and Teosinte forage in feeding of growing Zaraibia goats. Egypt. J. Appl. Sci., 12 (5): 63.

SPSS, 1999. SPSS Basa 75 for Windows. User's Guide: SPSS Inc. USA.

Tabana, A. S., 1994. Utilization of corn and sunflower plant residues in ruminants nutrition. M. SC. Thesis, Fac. Agric., Cairo Univ., Egypt.

Thomas, V. M., G. A. Murray, D. L. Thacker and D. N. Sneddon, 1982. Sunflower silage in rations for lactating Holstein cows. J. Dairy Sci., 65: 267 -270 .

Tyrrell, H. F. and P.W. Moe, 1975. Effect of intake on digestive efficiency. J. Dairy Sci., 58: 1151.

Valdez, F. R., J. H. Harrison, D. A. Deetz and S. C. Fransen, 1988a. In vivo digestibility of corn and corn sunflower intercropped as a silage crop. J. Dairy Sci., 71: $1860-1867$.

Valdez, F. R., J. H. Harrison, and S. C. Fransen, 1988b. Effect of feeding corn sunflower silage on milk production, milk composition and rumen fermentation of lactating dairy cows. J. Dairy Sci., 71: 2462 - 2469.

Vandersall, J. H., 1976. Sunflower silage for lactating dairy cows. J. Anim. Sci., 42: $1583-1584$.

Van Keuleun, J. and B. A. Young, 1977. Evaluation of acid - insoluble ash as a natural marker in ruminants digestibility studies. J. Anim. Sc., 44: 282 - 287. 
تقييم غذائي لسيلاج دوار الشمس بواسطة المجترات

رأفت إبراهيم معوض'، رضا السيد أحمد الثرايحي'، مصطفى حسين طحة'

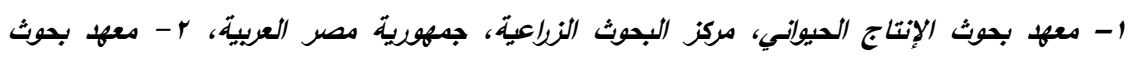

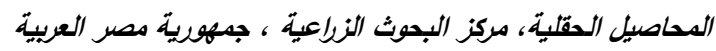

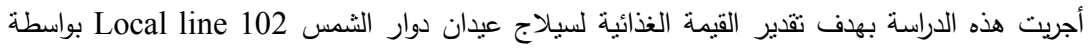
الأغنام وكذلك دراسة تأثير إضافته إلى علائق الجاموس الحلاب على أداءها الإنتاجي ومقارنته بسيلاج عيدان

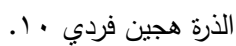

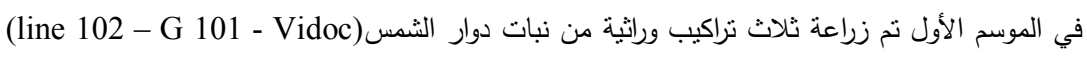
وتم اختيار التركيب الوراثي المحلي (line 102) بسبب تفوقه على الصنفين الأخريين في إنتاج الزيت وتركيبه

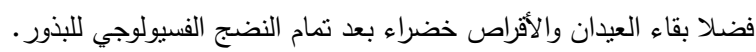

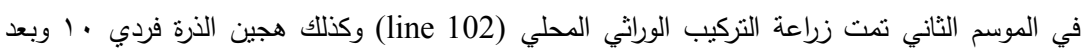

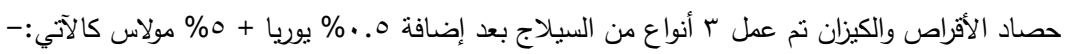

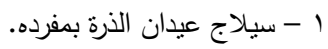
r - سيلاج عيدان (دوار الثمس + الذرة)، حيث تم خلط العيدان عند الكمر بمعدل .0\% من من كل نوع. r - سيلاج عيدان دوار الثمس بمفرده.

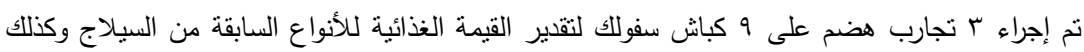

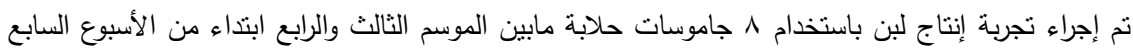

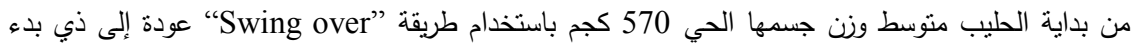

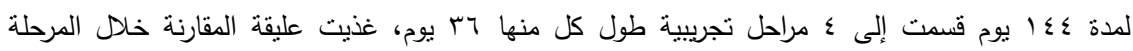

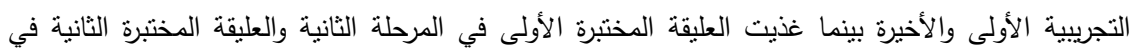
المرحلة الثالثة وقد غذيت الحيوانات تغذية فردية على العلائق النجريبية التالية: • عليقة المقارنة: .0\% من احتياجات الجاموس من المركبات الغذائية الكلية المهضومة والبروتين الخام من مخلوط العلف المركز + سيلاج عيدان الذرة للثبع. • عليقة مختبرة أولى: •0\% من احتياجات الجاموس من المركبات الغذائية الكلية المهضومة والبرون البروتين الخام

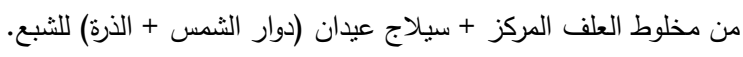

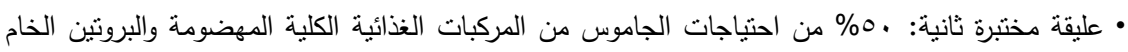

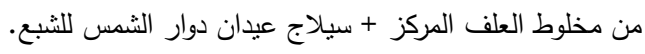

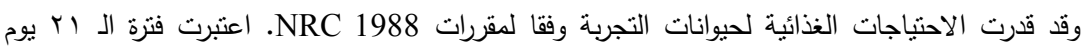

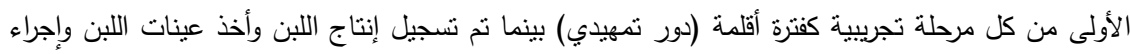

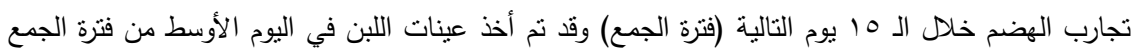

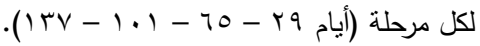


كانت أهم النتائج المتحصل عليها كما يلي:

• محتوى سيلاج دوار الثمس من المادة الجافة، البروتين الخام، الألياف الخام، الدهن الخام والرماد أعلى منها

في سيلاج عبدان الذرة بينما كان محتواه من المادة العضوية والمستخلص الخالي من النتروجين أقل.

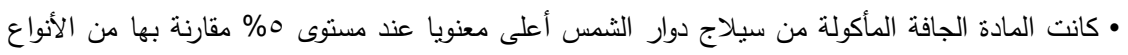

$$
\text { الأخرى من السيلاج. }
$$

• كانت معاملات هضم المادة الجافة والعضوية والمستخلص الخالي من النتروجين وكذلك قيمة المركبات الغذائية الكلبة المهضومة لسيلاج دوار الثمس أقل معنويا عند مستوى معنوية ه\% بينما كانت معاملات هضم البروتين الخام والدهن الخام وكذلك قيمة البروتين الخام المهضوم أعلى معنويا وذلك مقارنة بالقيم المقابلة لسيلاج عيدان الذرة؛ في حين كانت قيم معاملات هضم المركبات الغذائية والقيمة الغذائية لسيلاج

$$
\text { عيدان (دوار الثمس + الذرة) منوسطة. }
$$

• لا توجد اختلافات معنوية في المادة الجافة المأكولة من العلائق الثثلاثة بواسطة الجاموس الحلاب. • لا توجد اختلافات معنوية عند مستوى معنوية 0\% في معاملات هضم المادة الجافة والألياف الخام والدهن الخام في العلائق الثلاثة بواسطة الجاموس الحلاب بينما ارتفع معامل هضم البروتين الخام معنويا للعليقتين المختبرنين الأولى والثانية مقارنة بعليقة المقارنة. • كانت قيمة المركبات الغذائية الكلية المهضومة للعليقة المختبرة الثانية أقل معنويا بينما كانت قيمة البروتين لئهين الخام المهضوم أعلى معنويا عند مستوى معنوية ه\% مقارنة بالقيم المقابلة للعليقة المقارنة والعليقة المختبرة الأولى. • كان إنتاج اللبن الخام والمعدل لنسبة V\% دهن ومحصول الدهن أقل معنويا للحيوانات الدغذاة على العليقة المختبرة الثانية مقارنة بتلك المغذاة على العليقتين الأخريين، بينما لم تؤثر تغذية الحيوانات على عنى العليقة المختبرة الأولى معنويا على القباسات السابقة. • لا توجد اختلافات معنوية بين التركيب الكيماوي للبن المنتج من الجاموس المغذى على العلائق التجريبية الثلاثة.

• أظهرت النتائج أن إضافة سيلاج عيدان (دوار الثمس + الذرة) أو سيلاج عيدان دوار الثمس بنسبة حتى

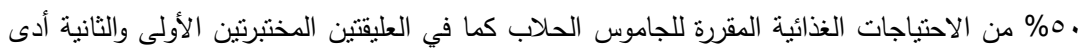

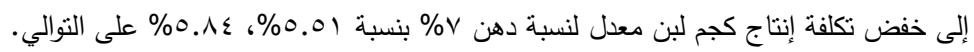
• من النتائج السابقة يتبين أن سيلاج عيدان دوار الثمس أو سيلاج مخلوط عيدان دوار الثمس + الذّان والئضاف إلى كل منهما عند التصنيع ه\% مولاس + 0. • \% يوريا يعتبر مادة مالئة مناسبة للمجترات

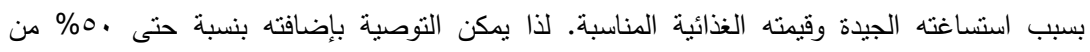
الاحتباجات الغذائية المقررة للجاموس الحلاب حيث أدى ذلك إلى خفض تكلفة التغذية وتحسين الكفاءة 